\title{
PENINGKATAN KETERAMPILAN MENULIS PUISI MENGGUNAKAN TEKNIK MIND MAPPING DI KELAS V SD
}

\author{
Maistika Ratih, Taufina \\ Universitas Negeri Padang, Indonesia \\ Email: maistikaratihmbc@gmail.com
}

\begin{abstract}
ABSTRAK
Studi pendahuluan dilakukan bahwa dalam menulis puisi masih banyak ditemui kesulitan dan hambatan yang dihadapi oleh peserta didik seperti sulit menuangkan idenya dalam bentuk puisi, hal ini terjadi karena media pembelajaran yang digunakan pendidik masih kurang menarik, pendidik belum memanfaatkan media sebagai objek dalam menulis puisi. Penelitian ini bertujuan meningkatkan keterampilan menulis puisi menggunakan teknik mind mapping di kelas V SDN 01 Koto Merapak. Jenis penelitian ini penelitian tindakan kelas yang dilakukan dua siklus, dengan tahap perencanaan, pelaksanaan, pengamatan, dan refleksi. Penelitian ini dilaksanakan pada semester II Tahun ajaran 2018/2019 di SDN 01 Koto Merapak. Subjek penelitian adalah peserta didik kelas V SDN 01 Koto Merapak. dengan jumlah 32 orang peserta didik. instrumen penelitian adalah lembar pengamatan, lembar tes lembar catatan lapangan, dan dokumentasi. Hasil penelitian menunjukkan bahwa keterampilan menulis puisi menggunakan teknik Mind Mapping dapat meningkatkan keterampilan menulis puisi peserta didik di SDN 01 Koto Merapak. Hal ini tampak dari hasil keterampilan menulis puisi siklus I pertemuan I memperoleh rata-rata $69.78 \%$ dengan kriteria (C), meningkat pada siklus I pertemuan II memperoleh rata-rata $74.12 \%$ dengan kriteria Baik (B), dan meningkat pada siklus II memperoleh rata-rata $88.74 \%$ dengan kriteria Sangat Baik (SB). Jadi disimpulkan bahwa kemampuan katerampilan menulis puisi dapat meningkat menggunakan Teknik Mind Mapping.
\end{abstract}

Kata Kunci: Peningkatan; Menulis Puisi; Teknik Mind Mapping.

\begin{abstract}
Preliminary studies conducted in writing poetry found that there were still many difficulties and obstacles encountered by students such as the difficulty of pouring their ideas in poetry form. This problem happens because the learning media used by educators were still less attractive as the educators had not used the media as objects in writing poetry. This research aimed to improve poetry writing skills by using mind mapping techniques in class V SDN 01 Koto Merapak. This research employs classroom action research conducted in two cycles with the stages of planning, implementation, observation, and reflection. This research was conducted in semester II of the 2018/2019 school year at SDN 01 Koto Merapak. The subjects of the research were students of class V SDN 01 Koto Merapak. with a total of 32 students. The research instruments were observation sheets, test sheets, field notes sheets, and documentation. The results showed that poetry writing skills using Mind Mapping techniques can improve students' poetry writing skills at SDN 01 Koto Merapak. This result was evidenced from the results of the poetry writing skills of the first cycle meeting I gained an average score of $69.78 \%$ with Pass criteria (C), increased in the first cycle meeting II gained an average score of $74.12 \%$ with Good criteria (B), and increased in the second cycle obtained an average score of $88.74 \%$ with criteria Very Good (SB). It was concluded that the ability to write poetry skills can be improved by using Mind Mapping Techniques
\end{abstract}

Keywords: Enhancement; Writing Skills; Mind Mapping Techniques. 


\section{PENDAHULUAN}

Pendidikan dasar merupakan jenjang pendidikan terbawah dari sistem pendidikan nasional yang ditetapkan dalam Undang-Undang Nomor 20 Tahun 2003 tentang Sistem Pendidikan Nasional. Pendidikan dasar diselenggarakan untuk mengembangkan sikap dan kemampuan serta memberikan pengetahuan dan keterampilan dasar yang diperlukan untuk hidup dalam masyarakat serta mempersiapkan peserta didik yang memenuhi persyaratan untuk mengikuti pendidikan tingkat menengah. Susanto (2013) menyatakan bahwa "sekolah dasar pada dasarnya merupakan lembaga pendidikan yang menyelenggarakan program pendidikan enam tahun bagi anak-anak usia 6-12 tahun." Usia sekolah merupakan masa peserta didik memperoleh dasar-dasar pengetahuan untuk keberhasilan penyesuaian diri pada kehidupan dewasa dan memperoleh keterampilan tertentu. Menurut Tarigan (2008:1) "Pembelajaran bahasa Indonesia mencakup empat aspek keterampilan yaitu keterampilan mendengarkan, berbicara, membaca dan menulis". Berdasarkan KTSP 2006, keterampilan berbahasa di SD salah satunya keterampilan menulis. Menurut Walshe dalam Solahudin 2007 (dalam Susanto, 2013:248), "Menulis merupakan bentuk belajar yang paling andal dan hampir semua bentuk kegiatan menulis mempunyai komponen ' 'belajar untuk menulis dan menulis untuk belajar".

Berdasarkan pendapat di atas, menulis merupakan suatu kegiatan yang tidak dapat dipisahkan dengan kehidupan manusia, karena manusia melakukan kegiatan berbahasa dalam kehidupannya melalui bahasa lisan dan tulisan. Selain keterampilan menulis, di SD ada yang namanya menulis puisi. Salah satu manfaat yang ingin diperoleh dalam pembelajaran menulis adalah menciptakan suasana belajar yang menyenangkan bagi siswa (Ahmad, 2019)

Menurut Faisal, dkk (2009: 7-13), puisi merupakan karya sastra yang berbentuk untaian bait demi bait yang relatif memperhatikan irama dan rima sehingga sungguh indah dan efektif didendangkan dalam waktu yang relatif singkat dibandingkan bentuk karya sastra lainnya. Menulis puisi salah satu hal yang penting untuk dipelajari, dan merupakan sebuah kegiatan rohani yang mengekspresikan hubungan manusia dengan segala hal, baik secara fisik maupun metafisik, untuk 
bisa menulis puisi perlu latihan secara rutin. Latihan menulis puisi ini bertujuan untuk mempertajam pengamatan dan meningkatkan kemampuan bahasa.

Berdasarkan wawancara tidak terstruktur dan observasi yang dilaksanakan di kelas V SDN 01 Koto Merapak pada saat proses pembelajaran bahasa Indonesia, yaitu pada hari Senin dan Kamis, tanggal 14 dan 17 Agustus 2019. Peneliti menemukan beberapa fenomena yang terjadi diantaranya, dari segi pendidik yaitu (1) pendidik belum membuka skemata peserta didik dalam menulis puisi, (2) dalam membuat tema puisi, pendidik belum menggunakan media gambar, (3) pendidik belum bisa menarik perhatian peserta didik dalam menulis puisi, (4) peserta didik belum diajak memetakan pikirannya dan menghubungkan pikiran tersebut dengan sebuah tema puisi, dan (5) peserta didik belum diminta untuk menemukan kata kunci yang berkaitan dengan tema puisi. Akibat proses pembelajaran tersebut terhadap peserta didik adalah (1) peserta didik kesulitan menemukan ide untuk menulis puisi, (2) peserta didik sulit membayangkan apa yang ingin mereka tuangkan dalam membuat puisi, (3) proses menulis puisi cendrung membosankan dan kurang menarik, (4) peserta didik kesulitan mengembangkan ide menjadi puisi dan peserta didik kurang mampu menghubungkan antara dunia khayal dengan dunia nyata ke dalam puisi, dan (5) peserta didik sulit merangkai kata menjadi sebuah kalimat puisi yang baik. Apabila kondisi pembelajaran di atas dibiarkan terus berlanjut maka akan berdampak negatif terhadap proses pembelajaran dalam menulis puisi bagi peserta didik di kelas V SDN 01 Koto Merapak.

. Salah satu upaya yang dapat mengatasi kondisi di atas perlu diadakan pembaharuan pada teknik pembelajaran sehingga tidak membuat peserta didik cepat bosan, lebih kritis, aktif dalam pembelajaran, sehingga mencapai tujuan pembelajaran menulis puisi. Salah satu teknik pembelajaran yang dapat digunakan untuk memperbaiki permasalahan di atas adalah dengan menggunakan teknik mind mapping.

Mind mapping merupakan diagram yang tersusun atas kata-kata kunci dan gambar-gambar (Suparmi et al., 2019) sedangkan Buzan (2005:4-5) Mind Mapping adalah cara termudah untuk menempatkan informasi ke dalam otak dan mengambil informasi keluar dari otak, Mind Mapping adalah cara mencatat yang kreatif, efektif, dan secara harfiah akan "memetakan" pikiran-pikiran kita. Mind Mapping 
juga merupakan peta rute yang hebat bagi ingatan, memungkinkan kita menyusun fakta dan pikiran sedemikian rupa sehingga cara kerja alami otak dilibatkan sejak awal. Ini berarti mengingatkan informasi akan lebih mudah dan lebih bisa diandalkan dari pada menggunakan teknik biasa. Mind Mapping (peta pikiran) adalah suatu teknik mencatat yang mengembangkan gaya belajar visual. Peta pikiran memadukan dan mengembangkan potensi kerja otak yang terdapat di dalam diri seseorang, dengan adanya keterlibatan kedua belah otak, maka akan memudahkan seseorang untuk mengatur dan mengingat segala bentuk informasi, baik secara tertulis maupun secara verbal.

Berdasarkan pendapat ahli di atas, jelaslah bahwa mind mapping adalah suatu cara termudah untuk menempatkan informasi di dalam otak berdasarkan cara kerja yang alami, sehingga meningkatkan potensi kerja otak yang terdapat di dalam diri seseorang dan lebih mudah untuk mengingat segala informasi, baik secara tulisan maupun verbal.

Melalui teknik mind mapping diharapkan dapat meningkatkan motivasi belajar siswa, melatih daya imajinatif dan kreativitas siswa, membangun pengetahuan siswa, melatih memahami materi melalui kata-kata kunci, melatih menjelaskan hubungan-hubungan antarbagian materi, serta melatih berpikir secara lebih(Fadillah \& Indonesia, 2019)

Kelebihan mind mapping menurut Taufik dan Muhammadi (2011:176) mengemukakan, "Ada beberapa kelebihan saat menggunakan teknik mind mapping, yaitu : (1) cara ini cepat, (2) teknik ini dapat digunakan untuk mengorganisasikan ide-ide yang muncul di kepala, (3) proses menggambar diagram bisa dimunculkan ide-ide yang lain, dan (4) diagram yang sudah terbentuk bisa menjadi panduan untuk menulis

Keterampilan dalam menulis puisi akan terlaksana dengan baik apabila prosesnya berjalan dengan lancar. Adapun teknik mind mapping menurut Buzan (2005:14) untuk meningkatkan keterampilan menulis puisi yaitu:

(1) tahap pramenulis dengan beberapa teknik mind mapping (a) mulai dari bagian tengah kerta kosong yang sisi penjangnya diletakkan landscape (mendatar), (b) gunakan gambar atau foto untuk ide sentra, (c) gunakan spidol warna-warni dengan memberikan warna yang berbeda pada setiap cabangnya, (d) hubungkan 
cabang-cabang utama ke gambar pusat dan hubungkan cabang-cabang tingkat dua dan tiga ke tingkat satu dan dua dan seterusnya, (e) buatlah garis hubung yang melengkung yang mengecil dari pangkal menuju ujung, (2) tahap saat menulis dengan beberapa teknik mind mapping (a) gunakan satu keyword (kata kunci) untuk setiap garis, dan (3) tahap pasca menulis dengan beberapa teknik mind mapping yaitu: (a) gunakan key image (kata bergambar) .

Berdasarkan pendapat ahli di atas, bahwa teknik mind mapping dapat membantu peserta didik memperoleh ide yang ingin diceritakan, memberi kemudahan dalam memulai menulis puisi, menciptakan pembelajaran yang menarik dan tidak monoton, pembelajaran ini sangat cocok untuk melihat pengetahuan awal peserta didik, sehingga menciptakan suasana yang menyenangkan bagi peserta didik.

Menulis dalam proses pembelajaran merupakan aktifitas yang berpengaruh terhadap pendidikan terutama dalam intelektual peserta didik. Pengertian Intelektual (Kecerdasan) Kamus Besar Bahasa Indonesia (Dalam Nyoman, 2015), mengartikan kecerdasan sebagai Perihal cerdas (sebagai kata benda), atau kesempurnaan perkembangan akal budi (seperti kepandaian dan ketajaman fikiran). Para ahli psikologis mengartikan kecerdasan sebagai keseluruhan kemampuan individu untuk memperoleh pengetahuan, menguasai dan mempraktekkannya dalam pemecahan suatu masalah (Yani dalam Nyoman, 2011: 53)

Hasil dari penelitian dari (Hendriyanto \& Hendrayani, 2019), dengan judul "meningkatkan keterampilan siswa menulis teks report dengan pembelajaran mind mapping berbasis multimedia" hasil penelitian menunjukkan bahwa keberhasilan siswa meningkat secara signifikan hingga 75,00 menggunakan 2 siklus, oleh karena itu peneliti tertarik untuk mengadakan penelitian tindakan kelas dengan judul "Peningkatan Keterampilan Menulis Puisi Menggunakan Teknik mind mapping Bagi Peserta didik Kelas V SDN 01 Koto Merapak."

Berdasarkan studi pendahuluan yang dilakukan, peneliti merumuskan masalah yaitu "bagaimana peningkatan keterampilan menulis puisi menggunakan teknik mind mapping bagi peserta didik kelas V SDN 01 Koto Merapak. Adapun tujuan Penelitian untuk mendekripsikan peningkatan keterampilan menulis puisi 
menggunakan teknik mind mapping bagi peserta didik kelas V SDN 01 Koto Merapak dengan tahapan pramenulis, saat menulis dan pasca menulis.

\section{METODE}

Penelitian ini merupakan penelitian kualitatif dan kuantitaif, sebagaimana kualitatif menjelaskan proses siklus berjalan sedangkan kuantitatif mejelaskan terkait angka dan peningkatan secara signifikan hasil belajar peserta didik, oleh karena itu penelitian ini dilakukan beberapa siklus, siklus 1 dengan 2 kali pertemuan sedangkan siklus 21 kali pertemuan, siklus yang dilakukan hanya sampai siklus 2 sebagaimana hasil dari penelitian sudah nampak jelas perubahan terhadap keterampilan menulis puisi dengan teknik mind mapping oleh sebab itu siklus diberhentikan sampai siklus 2. Sumber data dalam penelitian ini adalah siswa kelas $\mathrm{V}$ dan guru kelas. Metode pengumpulan data yang digunakan adalah metode lembar pengamatan, lembar tes lembar catatan lapangan. Metode tes digunakan untuk mengetahui kemampuan awal peserta didik dalam menulis puisi. mengumpulkan data, catatan lapangan dilihat dari permasalahan yang terjadi dengan mengamati kegiatan peserta didik, dokumentasi diambil saat kegiatan tes berlangsung atau halhal yang terkait kepentingan dalam penelitian ini.

Data yang diperoleh dalam penelitian ini diolah dengan analisis deskriptif kualitatif. Analisis data dalam penelitian yang dilaksanakan ini berlangsung bersamaan dengan proses pengumpulan data. Pengolahan data tersebut di antaranya adalah melalui tiga tahap model alur, yaitu reduksi data, penyajian data, dan verifikasi data. Teknik yang digunakan dalam memeriksa keabsahan data dan kejenuhan data dalam penelitian ini adalah ketekunan pengamatan dan triangulasi data. Triangulasi data yang dilaksanakan menggunakan dua cara, yaitu melalui sumber dan teori.

\section{HASIL DAN PEMBAHASAN}

Berdasarkan penelitian di lakukan, bahwa penelitian ini dilaksanakan pada kelas V SDN 01 koto merapak pada tahun ajaran 2018/2019 dengan jumlah peserta didik 32 orang, yang terdiri dari 15 orang laki-laki dan 17 orang perempuan, dalam penelitian ini peneliti bertindak sebagai pendidik, sedangkan pendidik kelas $\mathrm{V}$ 
bertindak sebagai pengamat. Penelitian ini dilaksanakan II siklus, siklus I terdiri II kali pertemuan dan siklus II terdiri I kali pertemuan. siklus I pertemuan I, memperoleh persentase $69.78 \%$ dengan kriteria Cukup (C), sedangkan pada siklus I pertemuan II memperoleh persentase $74.12 \%$ dengan kriteria Baik (B) meningkat pada siklus II menjadi $88.74 \%$ dengan kriteria Amat Baik (AB).

Pembahasan hasil penelitian pada siklus I dan II meliputi: 1) peningkatan kemampuan menulis puisi dengan menggunakan teknik mind mapping pada tahap pramenulis di kelas V SDN 01 Koto Merapak, 2) peningkatan keterampilan menulis puisi dengan menggunakan teknik mind mapping pada tahap saat menulis di kelas V SDN 01 Koto Merapak, 3) peningkatan kemampuan dalam menulis puisi dengan menggunakan teknik mind mapping pada tahap pascamenulis di kelas V SDN 01 Koto Merapak, dan (4) hasil penilaian keterampilan menulis puisi dengan menggunakan teknik mind mapping di kelas V SDN 01 Koto Merapak. Pembahasan hasil penelitian siklus I dan 2 dapat dijelaskan sebagai berikut:

a. Peningkatan keterampilan Menulis Puisi dengan Menggunakan Teknik Mind Mapping pada Tahap Pramenulis di kelas V SDN 01 Koto Merapak

Pembelajaran menulis puisi dengan menggunakan teknik mind mapping pada pramenulis bagi peserta didik kelas V SDN 01 Koto Merapak Padang diawali mengkondisikan kelas, berdo'a, dan memeriksa kehadiran peserta didik (absensi). Setelah kegiatan tersebut, peneliti melaksanakan kegiatan tahap pramenulis.

Peningkatan keterampilan menulis puisi dengan teknik mind mapping di kelas V SDN 01 Koto Merapak pada tahap pramenulis, dalam proses pembelajarannya terdapat kegiatan presentasi kelas. Kegiatan presentasi kelas diawali peneliti dengan menyampaikan tujuan pembelajaran. Penyampaian tujuan pembelajaran bertujuan untuk memfokuskan pikiran peserta didik terhadap apa yang harus dicapai dan dikuasai peserta didik dalam pembelajaran sehingga peserta didik tidak merasa kesulitan dalam proses pembelajaran. Selain itu, penyampaian tujuan pembelajaran penting dilakukan karena dapat membantu mengarahkan peserta didik dalam memahami apa yang akan dikerjakan serta untuk mencapai hasil belajar yang diinginkan. Kegiatan penyampaian materi sudah dilaksanakan dengan baik oleh peneliti. Hal ini dapat terlihat dari bahasa dan kalimat yang digunakan penulis dalam penyampaian tujuan pembelajaran sangat jelas dan mudah dimengerti. 
Peneliti menyampaikan maksud dari mind mapping dan penerapannya dalam menulis puisi sehingga peserta didik sudah dapat memprediksi kegiatan yang akan dilaksanakannya pada proses pembelajaran menulis puisi dengan teknik mind mapping.

Kegiatan selanjutnya, menentukan topik/tema tulisan. Kegiatan ini bertujuan untuk membantu peserta didik memperoleh ide atau gagasan yang akan ditulis. Resmini dan Juanda (2008:119) mengemukakan "Gagasan peserta didik sangat erat dengan pengetahuan (skemata) peserta didik. Namun, tidak setiap peserta didik mempunyai gagasan yang akan ditulisnya. Untuk mengatasi hal itu, peserta didik dapat membaca atau menelaah bentuk tulisan, mendengar cerita atau dongeng, dan mendengarkan pengalaman orang lain". Berdasarkan pendapat Resmini dan Juanda tersebut, maka peneliti berupaya membangkitkan skemata peserta didik dengan menentukan sebuah topik atau tema tulisan dengan mendengarkan pengalaman orang lain mengenai suatu tema. Tema yang dipilih yaitu "keluarga". Peneliti meminta peserta didik menceritakan pengalamannya mengenai keluarga di depan kelas, sedangkan peserta didik yang lain mendengarkan cerita pengalaman teman dengan seksama.

Selanjutnya, peneliti menjelaskan cara membuat mind mapping kepada peserta didik dengan langsung mendemonstrasikan mind mapping di papan tulis. Sebagian besar peserta didik sudah mendengarkan peneliti dalam menjelaskan cara membuat mind mapping. Sebagian besar peserta didik sudah mendengarkan penjelasan penulis mengenai cara membuat mind mapping, sehingga kegiatan ini sudah mencapai kriteria Sangat Baik (SB) pada aspek pendidik dan peserta didik. Setelah memberikan penjelasan mengenai cara membuat mind mapping, peneliti membagikan selembar kertas kosong, kemudian penulis meminta peserta didik untuk mulai membuat tema dan gambar sentral di tengah kertas kosong tersebut. Buzan (dalam Taufik dan Muhammadi 2011:350) mengemukakan "Mulailah membuat mind mapping dari bagian tengah kertas kosong yang sisi panjangnya diletakkan mendatar karena memulai dari tengah memberi kebebasan kepada otak untuk menyebar ke segala arah dan untuk mengungkapkan dirinya dengan lebih bebas dan alami”. Peneliti mengarahkan dan mendemonstrasikan membuat tema 
dan gambar sentral di hadapan peserta didik dengan baik, sehingga semua peserta didik sudah paham membuat tema dan gambar sentral.

Kegiatan selanjutnya, peneliti mengarahkan peserta didik dalam untuk membuat cabang mind mapping yang menggunakan banyak warna dengan cabang yang mengecil ke ujung. Buzan (dalam Taufik dan Muhammadi 2011: 351) mengemukakan "Gunakan warna dalam mind mapping karena bagi otak, warna membuat mind mapping lebih hidup, menambah energi kepada pemikiran kreatif dan menyenangkan". Pada siklus II masih terdapat peserta didik yang meminjam alat pewarna temannya, namun pembelajaran tidak terganggu karena penulis berupaya mengkondisikan kelas dengan baik. oleh sebab itu, sebagian peserta didik sudah paham membuat cabang mind mapping dengan banyak warna.

b. Peningkatan keterampilan Menulis Puisi dengan Menggunakan Teknik Mind Mapping pada Tahap Saat menulis di kelas V SDN 01 Koto Merapak

Pembelajaran menulis puisi dengan menggunakan teknik mind mapping pada saat menulis bagi peserta didik kelas V SDN 01 Koto Merapak diawali dengan penulis mengarahkan peserta didik menemukan kata kunci yang berkaitan dengan tema. Buzan (dalam Taufik dan Muhammadi 2011:352) mengemukakan "Bila kita menggunakan kata tunggal, setiap kata ini akan lebih bebas dan karenanya lebih memicu ide dan pikiran baru. Mind mapping memiliki lebih banyak kata kunci seperti tangan yang semua sendi jarinya bekerja". Sebagian besar peserta didik sudah paham dalam menemukan kata kunci yang berkaitan dengah tema karena di awal pembelajaran penulis sudah membuka skemata peserta didik dengan mendengarkan pengalaman teman dan gambar sentral. Namun, 2-4 orang peserta didik masih kesulitan menenemukan kata kunci yang berkaitan dengan tema.

Setelah menulis kata kunci pada cabang pertama mind mapping, peneliti mengarahkan peserta didik dalam menemukan dan menulis kata kunci pada cabang mind mapping tingkat berikutnya. Peneliti sudah mengarahkan peserta didik dengan baik, sehingga dalam kegiatan ini peserta didik sudah mulai paham menulis kata kunci pada setiap cabang mind mapping. Kegiatan selanjutnya adalah penulis menugasi peserta didik membuat gambar tambahan pada cabang mind mapping. Menurut Buzan (dalam Taufik dan Muhammadi 2011:352) mengemukakan “Gunakan gambar karena seperti gambar sentral, setiap gambar bermakna seribu 
kata. Jadi, bila kita hanya mempunyai 10 gambar di dalam mind mapping. Peneliti berupaya untuk memberikan pengarahan kepada peserta didik dalam membuat gambar tambahan pada cabang mind mapping. Sebagian besar peserta didik sudah mampu membuat gambar tambahan. Selain itu, peneliti berupaya memberikan motivasi kepada peserta didik yang kurang pandai dalam menggambar, sehingga peserta didik yang kurang percaya diri dengan kemampuannya berkurang dari siklus sebelumnya.

Kegiatan selanjutnya, peneliti menugasi peserta didik menulis puisi berdasarkan kata kunci dalam mind mapping. Peneliti menyebutkan satu contoh puisi berdasarkan mind mapping yang dibuat oleh salah satu peserta didik. Hal ini dilakukan penulis, agar peserta didik mendapat gambaran mengenai puisi yang akan ditulis berdasarkan kata kunci yang terdapat dalam mind mapping. Peserta didik sudah paham menulis puisi berdasarkan kata kunci mind mapping.

c. Peningkatan keterampilan Menulis Puisi dengan Menggunakan Teknik Mind Mapping pada Tahap Pascamenulis di kelas V SDN 01 Koto Merapak

Pembelajaran menulis puisi dengan menggunakan teknik mind mapping pada pascamenulis bagi peserta didik kelas V SDN 01 Koto Merapak. Peneliti meminta peserta didik untuk melakukan revisi/editing terhadap tulisannya. Pada siklus II, penulis berupaya memperbaiki kekurangan pada siklus I. Peneliti lebih rinci dalam menjelaskan hal-hal yang perlu direvisi/diedit oleh peserta didik, sehingga peserta didik yang sudah memiliki bekal revisi dan editing tulisan semakin paham dalam merevisi dan mengedit tulisannya. Selanjutnya, peneliti meminta peserta didik memperlihatkan puisi yang sudah direvisi dan diedit. Semua peserta didik sudah memperlihatkan puisinya kepada peneliti.

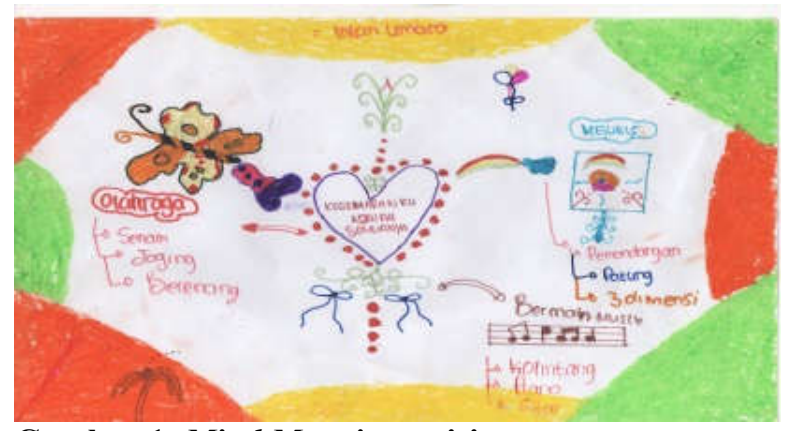

Gambar 1. Mind Mapping puisi

Maistika Ratih, Taufina, Peningkatan Keterampilan Menulis Puisi Menggunakan Teknik Mind Mapping di Kelas V SD 
d. Hasil Penilaian Peningkatan keterampilan Menulis Puisi dengan Menggunakan Teknik Mind Mapping di kelas V SDN 01 Koto Merapak.

Penilaian keterampilan menulis puisi dengan teknik mind mapping di kelas $\mathrm{V}$ SDN 01 Koto Merapak terdiri dari penilaian proses dan hasil. Penilaian proses siklus I dapat dilihat pada lembar observasi aspek pendidik dan aspek peserta didik pada siklus II. Berdasarkan analisis sebelumya, pada siklus I pertemuan II kegiatan menulis mengalami peningkatan dari persentase $74.12 \%$ dari siklus I Pertemuan II, menjadi $88.74 \%$ dengan kriteria Sangat Baik (SB).

Penilaian hasil keterampilan menulis puisi dengan teknik mind mapping dapat dilihat pada lembar penilaian dan lembar hasil perolehan skor peserta didik kelas V SDN 01 Koto Merapak dalam menulis puisi pada siklus I pertemuan I dan siklus I pertemuan II. Pada siklus I pertemuan I, rata-rata hasil menulis puisi peserta didik kelas V memperoleh persentase 69.78 \% dengan kriteria Cukup (C). Pada siklus I pertemuan II, keterampilan menulis puisi peserta didik kelas V SDN 01 Koto Merapak mengalami peningkatan, dengan persentase $74.12 \%$ dengan kriteria Baik (B), dan meningkat pada Siklus II keterampilan menulis puisi peserta didik memperoleh presentase 88.74 dengan Kriteria Sangat Baik (SB). 


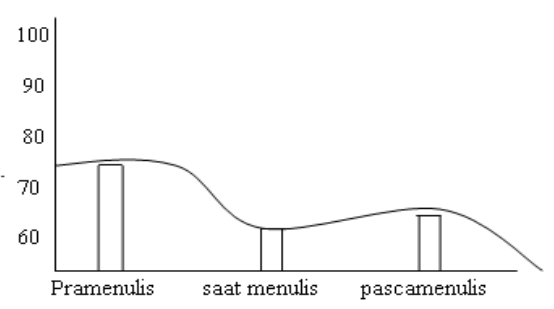

Grafik peningkatan menulis puisi siklus I PT I

Siklus $1 \mathrm{pt} 1$

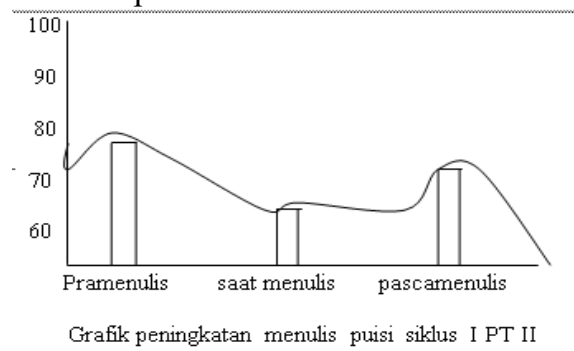

Siklus 1 pt 2

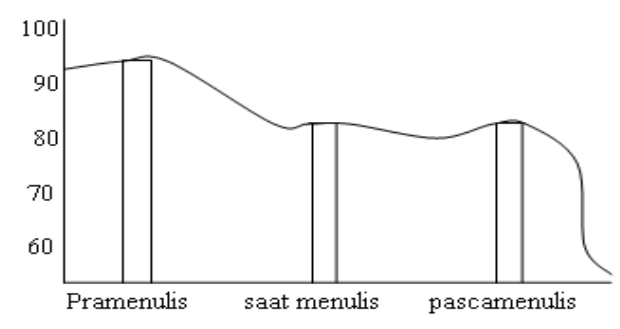

Grafik peningkatan menulis puisi siklus II

Siklus 2

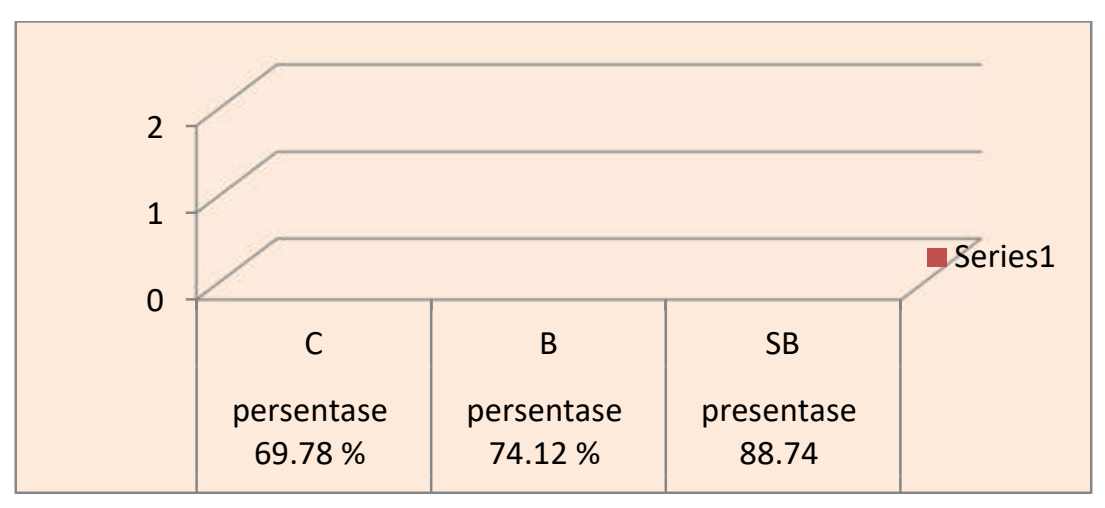

Gambar 3. Gambaran peningkatan keterampilan menulis puisi.

Berdasarkan penelitian di atas dapat disimpulkan bahwa menulis puisi menggunakan teknik mind mapping meningkat dengan baik, dari $69.78 \%$ menjadi $88.74 \%$.

Hasil penelitian terdahulu yang bersumber dari Review, Dasar, Pendidikan, \& Penelitian (2019) dengan judul Pengaruh Keterampilan Mind Mapping Terhadap Keterampilan Metakognitif Siswa Kelas V menunjukkan bahwa rata-rata nilai 
angket awal keterampilan metakognitif pada kelas eksperimen sebesar 68,12 (51,77 poin). Sedangkan, rata-rata nilai angket akhir keterampilan metakognitif pada kelas eksperimen sebesar 86,54 (65,77 poin). Dengan demikian terdapat peningkatan sebesar 18,42 (14 poin). Dengan nilai signifikansi sebesar 0,025. yang berada di bawah 0,05 terbukti ada pengaruh keterampilan mind mapping terhadap keterampilan metakognitif

Berdasarkan analisis data, rata-rata hasil post-test kelas eksperimen adalah 79,32, thitung 12,11 dan ttabel 1,694, karena thitung $>$ ttabel, maka Ha diterima. Jadi, dapat disimpulkan bahwa ada pengaruh model pembelajaran mind mapping terhadap hasil belajar siswa. Perhitungan ukuran efek yang diperoleh ES = 1,19 yang digolongkan tinggi, yaitu ES $>0,8$. Dapat dikatakan bahwa pembelajaran mind mapping memiliki peningkatan tinggi terhadap hasil belajar IPS pada siswa kelas V SD Negeri 41 Sungai Raya, keunggulan dari penelitian ini yaitu mampu memberikan hasil yang terbaik terhadap keterampilan menulis yang dilakukan menggunakan teknik mind mapping.

\section{SIMPULAN}

Hasil penelitian dan pembahasan, penelitian ini dilaksanakan pada kelas $\mathrm{V}$ SDN 01 Koto Merapak pada tahun ajaran 2018/2019 yang dilaksanakan II siklus, siklus I pertemuan I, memperoleh persentase 69.78\% dengan kriteria Cukup (C), sedangkan pada siklus I pertemuan II memperoleh persentase $74.12 \%$ dengan kriteria Baik (B) meningkat pada siklus II menjadi $88.74 \%$ dengan kriteria Amat Baik (AB). Kesimpulan bahwa menulis puisi menggunakan teknik mind mapping di kelas V SD meningkat secara signifikan yang dilaksanakan 2 siklus.

\section{DAFTAR PUSTAKA}

Ahmad, D. E. (2019). Perbandingan Model Pembelajaran Sinektik Dan Mind Mapping Dalam Keterampilan Menulis Teks Cerpen Siswa Kelas Ix Smp Handayani Sungguminasa Kabupaten Gowa.

Buzan, Tony. 2005. Buku Pintar Mind Mapp. Jakarta: PT. Gramedia Pustaka Utama. 
------. 2007. Buku Pintar Mind Mapp untuk Anak. Jakarta: PT. Gramedia Pustaka Utama.

Fadillah, U., \& Indonesia, P. B. (2019). Pengaruh Teknik Mind Mapping Berbasis Model Discovery Learning Terhadap Keterampilan Menulis Teks Laporan Hasil Observasi Siswa Kelas VII Smp Negeri 12 Padang, 214-219.

Faisal, M, dkk. 2009. Kajian Bahasa Indonesia SD. Jakarta: Dirjen Pendidikan Tinggi Depdiknas

Hendriyanto, D., \& Hendrayani, S. (2019). Meningkatkan Keterampilan Siswa Menulis Teks Report Dengan Pembelajaran Mind Mapping, 1(2), 92-100.

Nyoman. (2015). Pengaruh Kecerdasan Intelektual Pada Pemahaman Akuntansi Dengan Kecerdasan Emosi Dan Kecerdasan Spiritual Sebagai Variabel Pemoderasi.

Resmini, Novi dan Juanda, Dadan. 2008. Pendidikan Bahasa dan Sastra Indonesia di Kelas Tinggi. Bandung: UPI Press.

Resmini, Novi. dkk. 2008. Membaca dan Menulis di SD: Teori dan Pengajarannya. Bandung: UPI Press.

------. 2009. Pembinaan dan Pengembangan Pembelajaran Bahasa dan Sastra Indonesia. Bandung: UPI Press.

Review, J., Dasar, P., Pendidikan, J. K., \& Penelitian, H. (2019). Pengaruh Keterampilan Mind Mapping Terhadap Keterampilan Metakognitif Siswa Kelas V Mahasiswa Program Pascasarjana, Prodi Pendidikan Dasar, Universitas Negeri Surabaya, Dosen Pascasarjana, Prodi Pendidikan Dasar, Universitas Negeri Surabaya, 5(1).

Suparmi, S., Marhaeni, A., Artawan, G., Studi, P., Dasar, P., \& Pascasarjana, P. (2019). Menulis Ditinjau Dari Kemampuan Verbal Pada Siswa Kelas IV SDN 1 Dajan Peken Tabanan, 3(1), 12-20.

Susanto, Ahmad. 2013. Teori Belajar dan Pembelajaran di Sekolah Dasar. Jakarta: PT Fajar Interpratama Mandiri

Studi, P., Guru, P., Dasar, S., Dasar, J. P., Keguruan, F., Ilmu, D. A. N., \& Tanjungpura, U. (2019). Garuh Model Mind Mapping Terhadap Hasil Belajar. Tarigan, Henry Guntur. 2008. Menulis Sebagai Suatu Keterampilan Berbahasa. Bandung: PT. Angkasa Bandung 
Taufik dan Muhammadi. 2011. Mozaik Pembelajaran Inovatif. Padang: PT Sukabina Press

Quthb, Sayyid. 2004. Tafsir Fi-Zhilalil Qur'an: di bawah naungan Al-Qur'an jilid 11/cet 1. Jakarta: Gema Insani Press. 